JAMP: Jurnal Adminitrasi dan Manajemen Pendidikan

Volume 3 Nomor 1 Maret 2020, Hal : 38-51

Tersedia Online di http://journal2.um.ac.id/index.php/jamp/

ISSN 2615-8574 (online)

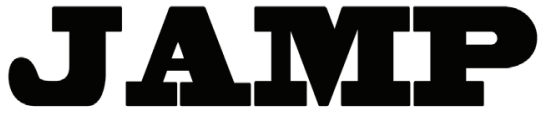

JURNAL ADMINISTRASI DAN MANAJEMEN PENDIDIKAN

\title{
PENERAPAN MANAJEMEN MUTU TERPADU PADA SISTEM PENJAMINAN MUTU PENDIDIKAN INTERNAL
}

\author{
Anne Sarvitri \\ Achmad Supriyanto \\ Agus Timan
}

\author{
Universitas Negeri Malang, Jl. Semarang No.5 Malang 65145 \\ Email: suryadianne@yahoo.com
}

\begin{abstract}
Educational Quality Assurance System (SPMP) has held internally in every kind and stage, of schools, including vocational secondary school. A good educational quality assurance is an "early warning system" so we can fix the problem from the early stage before it becomes harmful, which has a consequense in hardly to fix and bigger budget. Therefore, the quality assurance system is very important indeed. This study aims to provide an overview of the implementation of Integrated Quality Management (MMT) in vocational schools through the application of internal SPMP, and to find out the constraints and supporters of success. The research method uses description analysis by examining conditions, comparing them with indicators of implementation. The conclusion of this study shows TQM on internal SPMP have not been fully implemented. Quality management, vision statements, detailed plans, achievement awards, leadership, quality orientation, culture, communication, employee resistance, and resources, which have not been sufficient becoming barriers. On the other hand, education and training, empowerment and involvement of employees, customer focus, and commitment of top leaders, are supporters of successful implementation.
\end{abstract}

Key Words: Educational Quality Assurance System, Total Quality Management

\begin{abstract}
Abstrak. Sistem Penjaminan Mutu Pendidikan (SPMP) internal telah diterapkan di sekolah-sekolah dalam berbagai tingkatan, termasuk pada sekolah kejuruan. Sebuah sistem penjaminan mutu internal yang berjalan dengan baik merupakan "early warning system" atau sistem peringatan dini yang diharapkan dapat segera memperbaiki keadaan sebelum menjadi semakin parah, sehingga sulit diperbaiki dan berbiaya semakin mahal. Dengan demikian SPMP internal merupakan suatu hal yang sangat penting untuk dilakukan. Penelitian ini bertujuan untuk memberikan gambaran tentang implementasi dari Manajemen Mutu Terpadu (MMT) pada sekolah kejuruan melalui penerapan SPMP internal dan mengetahui penghambat dan pendukungnya. Metode penelitian menggunakan analisis deskripsi dengan menelaah kondisi dan membandingkannya dengan indikator implementasi. Kesimpulan dari penelitian ini menunjukkan MMT belum dilaksanakan sepenuhnya pada SPMP internal. Manajemen kualitas, pernyataan visi, pendetailan rencana, penghargaan prestasi, kepemimpinan, budaya orientasi mutu, komunikasi, resistensi pegawai, dan sumberdaya, yang belum memadai menjadi penghambat. Di lain pihak, pendidikan dan pelatihan, pemberdayaan dan pelibatan karyawan, fokus pelanggan, dan komitmen pemimpin puncak, menjadi pendukung keberhasilan implementasi.
\end{abstract}

Kata kunci: Sistem Penjaminan Mutu Pendidikan, Manajemen Mutu Terpadu

Memasuki abad baru yang dikenal dengan abad milenium, revolusi industri 4.0, atau masyarakat 5.0, kualitas merupakan suatu hal yang tidak dapat dilepaskan dari kehidupan sehari-hari. Bagaimana penerapan dari konsep kualitas pada dunia pendidikan harus benar-benar dipahami dan dibangun dengan landasan kejujuran untuk membangun sebuah sistem penjaminan mutu yang tepat. Apakah penjaminan 
mutu dalam dunia pendidikan lebih terarah kepada pembelajaran peserta didik, pemberdayaan guruguru, mendukung kerja tim, ataukah memberikan peluang luas bagi kepala sekolah selaku pemimpin sekolah untuk mengejar standar kualitas yang diharapkan.

Saat ini sudah muncul berbagai gerakan, kebijakan, dan aturan, yang mengarah kepada kegiatan penjaminan mutu, termasuk di sekolah kejuruan, seperti sekolah pada umumnya, sudah mulai menerapkan sistem penjaminan mutu. Kualitas sekolah yang baik seharusnya tidak menjadi bagian dari kegiatan politik pemerintah/pemerintah daerah, peringkat daerah berdasarkan pendidikan, atau kinerja sekolah semata, tetapi harus menjadi sebuah kebutuhan dari sekolah untuk terus berkembang di masa depan.

Salah satu hal yang menjadi penekanan dari 14 langkah Demings dalam Robbins (1999), Bapak dari gerakan Manajemen Mutu Terpadu (MMT) atau Total Quality Management (TQM) adalah mengurangi ketergantungan kepada pengawasan/inspeksi yang bersifat dari luar organisasi. Lebih memberdayakan upaya yang dilakukan diri sendiri, sehingga masalah dapat segera teratasi. Tetapi dalam hal ini seorang inspektor bukanlah orang yang ingin dihindari sama sekali keberadaaannya. Penjaminan mutu secara eksternal juga tetap perlu dilakukan untuk lebih melengkapi proses penjaminan mutu secara optimal. Sebuah sistem penjaminan mutu internal yang berjalan dengan baik juga menjadi sebuah "early warning system" atau sistem peringatan dini yang diharapkan dapat segera memperbaiki keadaan sebelum keadaan semakin parah atau berat, sehingga sulit diperbaiki atau berbiaya semakin mahal.

Seorang tokoh MMT, Phillip Crosby dalam Salis (2002), menyatakan "quality is free". Maksud pernyataan tersebut adalah bahwa jika sebuah tindakan dilakukan pada kesempatan pertama dan dilakukan dengan benar, maka tidak diperlukan biaya untuk memperbaiki kesalahan. Sebaliknya, jika hal ini tidak dilakukan dan terjadi kesalahan, maka akan dikeluarkan biaya yang tidak perlu untuk memperbaikinya.

MMT yang pada awalnya merupakan sebuah gerakan yang bersifat khusus untuk industri, kemudian beralih kepada bidang kehidupan lainnya termasuk pendidikan. Dunia pendidikan yang kompleks, mendorong lahirnya empat kepentingan kualitas (Four Quality Imperatives) hasil penelitian Sallis (2002) sebagai berikut. 1) The moral imperatives atau kepentingan moral. Pendidikan sebagai sebuah bidang yang bersentuhan langsung dengan kehidupan menyebabkan pelanggan utama dari pendidikan yaitu peserta didik, guru, dan komunitas, berhak mendapatkan kualitas terbaik dari pendidikan. Hal ini merupakan landasan moral dari penerapan penjaminan mutu. 2) The professional imperatives atau kepentingan profesional. Sangat dekat dengan kepentingan moral, sebagai sebuah profesi pendidik dan tenaga kependidikan, harus bekerja secara profesional untuk memberikan pelayanan terbaik kepada peserta didik baik di dalam kelas maupun di kegiatan lainnya. 3) The competitive imperatives. Dunia pendidikan sangat erat kaitannya dengan kompetisi. Jika tidak mampu berkompetisi, maka akan berpengaruh langsung pada tingkat pendaftaran peserta didik, yang pada akhirnya akan mempengaruhi kemampuan sekolah memberikan bayaran yang layak pada pendidik dan tenaga kependidikan. Sebuah sekolah digerakkan oleh keinginan melayani kebutuhan pelanggan utama yaitu peserta didik. 4) The accountability imperatives. Saat ini sekolah dituntut untuk bersifat akuntabel dan terbuka pada masyarakat untuk memenuhi standar yang diinginkan masyarakat. MMT mengarahkan kepada proses dan hasil yang terukur, dan juga memberikan mekanisme untuk peningkatan mutu.

Ismail (2014) dalam studinya terhadap sekolah menengah atas di Malaysia dengan mutu tinggi, sedang, dan rendah menunjukkan bahwa sekolah dengan mutu yang tinggi menerapkan MMT pada tingkatan yang paling tinggi dibandingkan dengan sekolah dengan mutu sedang dan rendah. Hal ini memberikan gambaran bahwa penerapan MMT penting dalam mempengaruhi kualitas mutu sebuah sekolah.

MMT yang berangkat dari filosofi dengan tujuan industrial harus hati-hati saat digeser ke arah pendidikan. Crawford dan Shutler (1999) menyatakan salah satu bahaya dalam mengikuti model 'zero defect' Crosby adalah sekolah menjadi berorientasi produk, peserta didik menjadi pasif, tidak fleksibel, kurang kreatif dan imajinatif. Produk dari pendidikan merupakan sesuatu yang kompleks, bukan produk dalam arti benda atau barang, tetapi suatu hasil dari peserta didik. Ini pun tidak mudah untuk dipahami. 
Produk dalam hal ini bukan semata-mata "jumlah lulusan", tetapi menyangkut pada perilaku dan etika peserta didik. Sehingga lebih tepat jika produk bukanlah hasil sistem produksi, tetapi lebih kepada pelayanan/service. Adapun pelanggan utama dari sebuah sistem pendidikan adalah peserta didik, baru selanjutnya adalah orangtua dan pemerintah.

Pekkar(1995) menyatakan "There is no single path to achieving total quality within an organization". Tidak ada suatu rumusan atau aturan baku yang dapat secara instan membawa suatu organisasi menjadi organisasi kelas dunia. Semua harus dikembalikan kepada aturan dan pedoman yang ada yang diikuti secara konstan dan terus-menerus. Hal ini karena kondisi dari setiap organisasi yang berbeda, orang yang berbeda, budaya yang berbeda. Apa yang berjalan pada suatu organisasi belum tentu sepenuhnya dapat ditiru oleh organisasi lain.

MMT merupakan sebuah rangkaian mindset atau pola berpikir, sekaligus sikap yang tercermin dalam keseharian perilaku. Berdasarkan Sallis (2002), terdapat beberapa hal yang menjadi ciri dari sebuah penerapan Manajemen Mutu Terpadu, yaitu: pertama, continous improvement. Sebuah organisasi yang menerapkan manajemen mutu terpadu harus secara terus-menerus melakukan perbaikan-perbaikan, yang bersifat sebuah siklus. Kesadaran akan pencapaian tujuan membuat organisasi terus melakukan analisis atas penerapan rencana yang mereka laksanakan dan melakukan perbaikan secara terus-menerus. Agar perbaikan menerus ini memungkinkan, maka seorang pemimpin harus memberikan kepercayaan kepada bawahannya untuk melakukan perbaikan sesuai dengan porsi tugas dan tanggung jawab mereka.

Kedua, kaizen. Istilah yang muncul dari Jepang ini paling tepat diterjemahkan sebagai step-by-step projects. Walaupun manajemen mutu terpadu sendiri merupakan kegiatan yang bersifat jangka panjang dan luas, tetapi dalam pelaksanaannya, dilakukan secara bagian per bagian kecil, yang dilakukan tetap dengan kerangka filosofi besar dari manajemen mutu terpadu.

Ketiga, perubahan budaya. Penerapan manajemen mutu terpadu bukan sekedar penerapan alat atau mekanisme tertentu yang dapat membuat sebuah organisasi berubah. Perubahan budaya juga bukan hanya perubahan pada perilaku sementara saja, tetapi menjadi bagian dari perubahan manajemen institusi. Dalam melakukan perubahan budaya, perlu diperhatikan dua hal, yaitu: Pertama, bawahan memerlukan sebuah lingkungan yang mendukung mereka menerapkan budaya mutu berupa sistem dan prosedur yang memudahkan. Tanpa adanya prosedur dan sistem yang perlu diikuti, para guru atau tenaga kependidikan akan bingung dan tidak mengetahui apa yang harus dilakukan. Kedua, untuk melakukan upaya-upaya perbaikan, bawahan memerlukan dorongan dan penghargaan dari atasan. Bawahan memerlukan atasan yang dapat menghargai pencapaian yang telah dilakukan, sekaligus menjadi mentor atau pendamping di dalam membuat perbaikan baru. Dalam hal ini diperlukan gaya kepemimpinan yang tepat.

Keempat, the upside down/inverted organization. Organisasi yang mendorong pada penerapan manajemen mutu terpadu secara prinsip berkebalikan dengan organisasi pada umumnya. Jika organisasi biasanya digambarkan sebagai sebuah susunan piramida, di mana staf pendukung bekerja untuk melayani staf pada jenjang yang lebih tinggi, misalnya guru, demikian selanjutnya sampai ke kepala sekolah. Maka pada organisasi yang menerapkan manajemen mutu terpadu, diterapkan kebalikannya di mana yang berada di bagian atas atau fokus pelayanan adalah pelanggan utama, yaitu peserta didik. Kemudian di bawahnya ada guru, manajemen, dan kepala sekolah. Tetapi secara organisasi, bukan berarti kepemimpinan kepala sekolah dihilangkan atau diubah, hanya secara prinsip, tujuan pelayanan diubah menjadi berorientasi kepada peserta didik.

Kelima, kedekatan dengan pelanggan. Di dalam dunia pendidikan, kedekatan dengan pelanggan yang dalam hal ini adalah peserta didik menjadi hal yang unik. Berbeda dengan dunia industri di mana pelanggan menginginkan sebuah produk yang jelas bentuk atau spesifikasinya untuk mereka konsumsi, di dalam dunia pendidikan, dapat menjadi sedikit sulit, karena pelanggan menilai mau seperti apa mereka belajar dan mendapatkan pengajaran, yang tidak semudah itu didefinisikan. Terkadang terdapat perbedaan antara apa yang menjadi keinginan sekolah dan keinginan peserta didik. Untuk mengatasi hal ini, manajemen sekolah perlu terus menggali motivasi dari peserta didik dan guru serta tenaga kependidikan sebagai pihak yang memberi layanan sehingga berada dalam motivasi dan frekuensi yang sama. 
Keenam, pelanggan internal. Sebuah penerapan manajemen mutu yang jarang dibahas adalah pelanggan internal. Maksud dari penerapan ini adalah bahwa dalam organisasi, seseorang atau sebuah bagian, merupakan pelayan sekaligus pelanggan bagi orang atau pihak lainnya. Hubungan antara staf internal sangat penting bagi sebuah organisasi jika mengharapkan organisasi tersebut berjalan secara efektif dan efisien. Cara termudah untuk mengetahuinya adalah dengan menanyakan 2 pertanyaan yaitu: siapa yang langsung anda layani?, dan siapa pihak yang untuk bekerja dengan benar tergantung pada hasil pekerjaan anda? Ini dikenal sebagai analisis next-in-line. Pelanggan langsung adalah mereka yang bekerja next-in-line dengan kita, dengan demikian perlu mengetahui dan memahami apa kebutuhan dan standar mereka. Dalam hal ini seorang pegawai muda tidak berbeda kebutuhannya dengan kepala sekolah dan perlu diberikan pelayanan yang sama baiknya.

Ketujuh, internal marketing/ pemasaran internal. Point ini juga hal yang jarang dibahas dalam manajemen mutu terpadu. Staf merupakan bagian yang menentukan perbedaan pelayanan. Dengan demikian menjadi sangat penting untuk terus menerus menyampaikan informasi pemasaran berkaitan dengan ide, produk, dan pelayanan yang akan diberikan kepada pelanggan/peserta didik, dengan demikian ide atau masukan staf dapat didengar dan menjadi bagian dari pengembangan.

Delapan, profesionalisme. Profesionalisme dunia pendidikan dalam beberapa bagian bisa jadi bertentangan dengan manajemen mutu terpadu. Dengan demikian perlu memberikan pelatihan dan pemahaman terhadap guru dan tenaga kependidikan tentang bagaimana pemaknaan sebuah kualitas. Pencapaian standar akademik dan kepedulian terhadap aspirasi dan keinginan peserta didik merupakan cerminan profesionalisme sekolah.

Terakhir yaitu kesembilan, kualitas pembelajaran. Jika berbicara tentang sekolah maka hal yang paling penting adalah tentang kualitas pembelajaran. Memberikan pelayanan pembelajaran yang benarbenar seusai dengan kebutuhan individu memang sangat sulit untuk diwujudkan, tetapi sebuah sekolah tidak akan dapat menyatakan bahwa dirinya telah menerapkan manajemen mutu terpadu jika kualitas pembelajaran yang dirasakan oleh peserta didik belum sesuai dengan harapan.

Sallis (2002) menjelaskan bahwa di dalam penerapan MMT pasti akan ada tentangan yang datang dari pihak internal organisasi. Kebiasaan dengan metode lama dan kesulitan di dalam penyesuaian terhadap suatu metode baru membuat sebagian orang menolak baik secara tersembunyi atau terangterangan terhadap perubahan mutu yang dibawa oleh MMT. Kekhawatiran dan penolakan terhadap MMT biasanya paling terasa di kalangan manajemen menengah, di sekolah kekhawatiran guru dan tenaga pendidik akan paling terasa karena mereka yang secara langsung melaksanakan kegiatan hari demi hari. Staf atau bawahan pun dapat merasakan kekhawatiran atas pemberdayaan yang dilakukan oleh pimpinan karena berkaitan dengan tanggung jawab yang dipikul jika ada kesalahan. Karena itu sangat penting bagi pimpinan untuk dapat menunjukkan manfaat dari MMT secara langsung, bukan sekedar jargon dan mengikuti trend saja. "Menyingkirkan rasa takut" seperti yang dinyatakan Demings memang perlu dilakukan di dalam menerapkan MMT.

Mosadeghrad (2012) menyatakan dalam penelitiannya bahwa hal yang menyebabkan paling seringnya terjadi kegagalan dalam penerapan MMT adalah: kurangnya pendidikan dan pelatihan berkaitan dengan mutu, kurangnya pelibatan karyawan, kurangnya dukungan dari pemimpin puncak, kurangnya sumber daya, kurangnya kepemimpinan, kurangnya budaya berorientasi mutu, lemahnya komunikasi, kurangnya rencana perubahan, dan resistensi dari pegawai di dalam perubahan program.

Arshida dan Agil (2013) menyatakan bahwa faktor keberhasilan dari penerapan MMT tergantung pada pendidikan dan pelatihan, manajemen kualitas, pemberdayaan karyawan, pernyataan visi dan rencana, penghargaan terhadap prestasi karyawan, dan fokus kepada pelanggan. Di sisi lain penelitian lebih lanjut menyatakan bahwa terdapat 3 faktor yang menyebabkan kegagalan dalam MMT dalam perusahaan yang diteliti yaitu: lemahnya pernyataan visi, kurangnya rencana detail atas penerapan MMT, dan kurangnya komitmen pemimpin puncak. 


\section{METODE}

Penelitian yang dilakukan di SMKS Kartika IV-1 Malang ini bertujuan untuk memberikan gambaran tentang implementasi dari MMT pada sekolah kejuruan melalui penerapan Sistem Manajemen Mutu Pendidikan (SPMP) internal yang terdapat dalam siklus pada Gambar 1 yang telah dilakukan oleh SMKS Kartika IV-1. Adapun penelitian ini tidak bermaksud untuk memberikan "treatment" atau perlakuan atas suatu kondisi, melainkan terbatas pada telaah atas kondisi sehingga lebih bersifat mengungkapkan data dan fakta yang ada, secara analisis deskripsi.

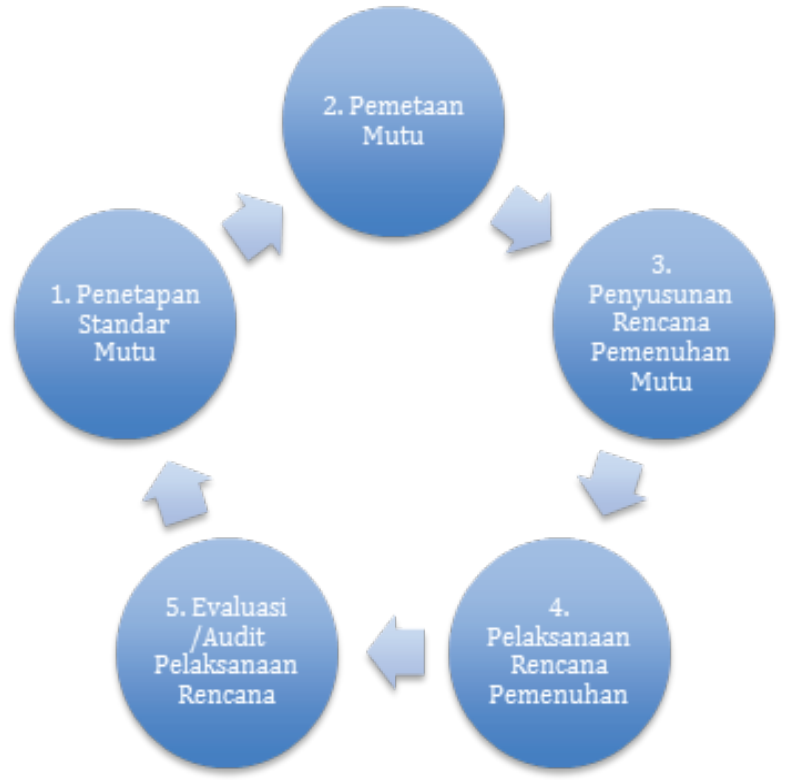

Gambar 1. Siklus Sistem Penjaminan Mutu Pendidikan Internal

Penelitian ini menggunakan daftar variabel yang kemudian diturunkan kembali kepada sub variabel dan indikator ketercapaiannya. Karena penelitian yang dirujuk sebelumnya bukan khusus pada dunia pendidikan tetapi lebih kepada dunia industri, maka perlu ditelaah dan dipilih kembali variabel, sub variabel, dan indikator yang akan digunakan.

Sebagaimana tercantum dalam Tabel 1, variabel yang digunakan adalah implementasi MMT pada SPMP, dengan dua sub variabel yaitu : keberhasilan implementasi dan hal-hal yang mendukung atau menghambat ketercapaian.

Tabel 1. Variabel, Sub Variabel, dan Indikator

\begin{tabular}{lll}
\hline \multicolumn{1}{c}{ Variabel } & \multicolumn{1}{c}{ Sub Variabel } & \multicolumn{1}{c}{ Indikator } \\
\hline Implementasi & Keberhasilan & Continous improvement \\
MMT pada & implementasi MMT pada & Kaizen \\
SPMP & SPMP & Perubahan budaya \\
& & Organisasi berkebalikan \\
& Kedekatan dengan pelanggan \\
& Pelanggan internal \\
& Pemasaran internal \\
& Profesionalisme \\
& Kualitas Pembelajaran
\end{tabular}




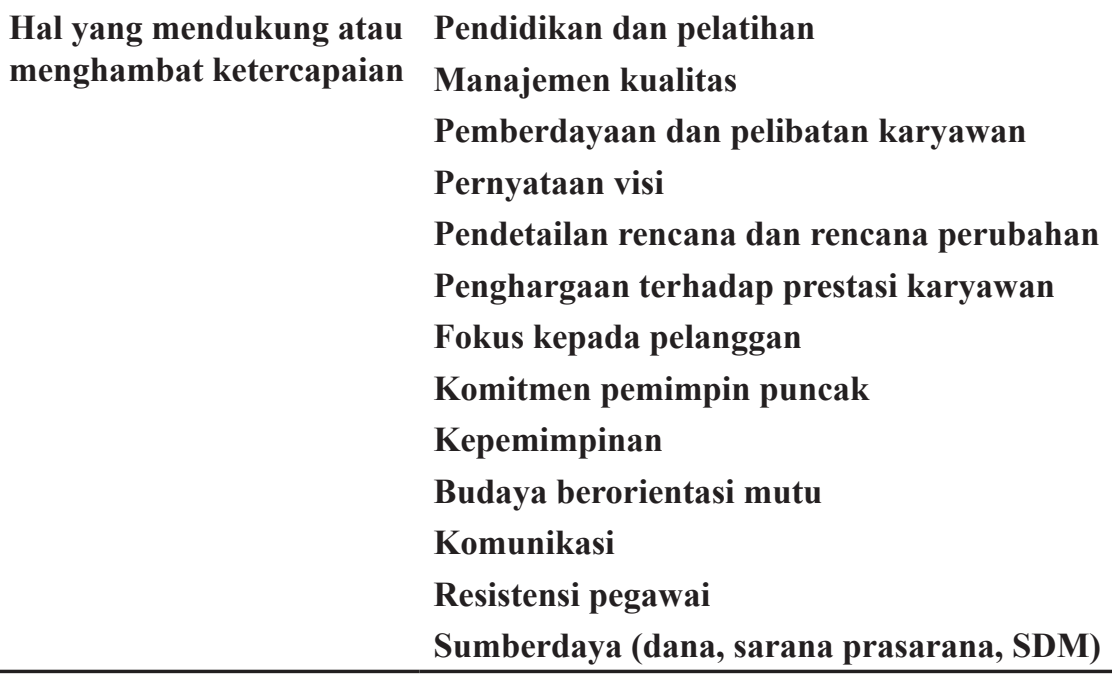

Penelitian ini menggunakan studi dokumenter atas data-data yang dimiliki oleh SMKS Kartika IV-1 Malang berupa rangkaian data hasil siklus penjaminan mutu internal yang ada di sekolah, yang terdiri dari: data Evaluasi Diri Sekolah (EDS), standar mutu, pemetaan mutu, rencana kerja (penyusunan rencana dan pelaksanaan), dan evaluasi atas rencana. Selanjutnya diterapkan teknik wawancara untuk mendapatkan masukan tentang penerapan, permasalahan, dan hambatan yang dihadapi sekolah. Wawancara dilakukan terhadap Ketua Tim Penjaminan Mutu Sekolah dan staf dalam Unit Penjaminan Mutu.

Teknik analisis deskriptif kualitatif digunakan untuk mengungkapkan keberhasilan implementasi MMT pada SPMP pada sekolah kejuruan. Langkah analisis meliputi pengumpulan data, reduksi data, analisis data, dan penarikan kesimpulan.

\section{HASIL DAN PEMBAHASAN}

\section{Gambaran tentang Pelaksanaan SPMP di Sekolah}

Pada saat melakukan penelitian di sekolah ini, peneliti melakukan pemeriksaan apakah sekolah telah melaksanakan seluruh siklus SPMP internal dengan hasil sebagai berikut:

- Sekolah telah melaksanakan siklus SPMP internal tetapi tidak secara utuh (bulat) karena:

1) kegiatan yang dilaksanakan tidak merupakan kelanjutan dari tahapan sebelumnya (atau hanya sebagian saja) misalnya saja dalam membuat perencanaan tidak berpedoman pada hasil pemetaan mutu, 2) ada kegiatan yang tidak dilaksanakan (misalnya evaluasi)

- Evaluasi yang dilaksanakan sekolah tidak secara langsung terkait dengan siklus SPMP internal sehingga indikator keberhasilan dari suatu program kurang terlihat

- Hasil dari Pemetaan Mutu terhadap 8 Standar Nasional Pendidikan (SNP) pada Tabel 2, secara umum SNP sekolah sudah cukup bagus. Seluruh nilai berada di atas standar propinsi dan hanya pada beberapa poin kurang dari SNP Kota Malang. Berdasarkan hal ini artinya sekolah telah masuk kategori yang baik dari sisi standar penilaian pendidikan. Tetapi di sisi lain, peneliti mengamati dan hasil wawancara menunjukkan sekolah masih kesulitan mendapatkan murid, kurang berprestasi, dan cenderung pada posisi manajemen bertahan karena banyaknya kelemahan. Hal ini memicu peneliti untuk melihat seperti apa proses SPMP yang telah dilaksanakan sekolah. Apakah MMT telah diterapkan pada proses tersebut atau belum. 
Tabel 2. Standar Nasional Pendidikan SMKS Kartika IV-1 Malang 2018

\begin{tabular}{llccc}
\hline No & \multicolumn{1}{c}{ Standar Nasional Pendidikan } & $\begin{array}{c}\text { Prop. } \\
\text { Jatim }\end{array}$ & $\begin{array}{c}\text { Kota } \\
\text { Malang }\end{array}$ & $\begin{array}{c}\text { SMKS Kartika } \\
\text { IV-1 Malang }\end{array}$ \\
\hline $\mathbf{1}$ & Standar Kompetensi Lulusan & $\mathbf{5 , 3 3}$ & $\mathbf{5 , 8 2}$ & $\mathbf{6 , 0 3}$ \\
$\mathbf{2}$ & Standar Isi & $\mathbf{4 , 9 1}$ & $\mathbf{5 , 3 7}$ & $\mathbf{5 , 5 2}$ \\
$\mathbf{3}$ & Standar Proses & $\mathbf{5 , 7 0}$ & $\mathbf{6 , 2 6}$ & $\mathbf{6 , 3 1}$ \\
$\mathbf{4}$ & Standar Penilaian Pendidikan & $\mathbf{5 , 5 7}$ & $\mathbf{5 , 7 7}$ & $\mathbf{5 , 6 5}$ \\
$\mathbf{5}$ & Standar Pendidik dan Tenaga Pendidikan & $\mathbf{3 , 1 5}$ & $\mathbf{4 , 2 1}$ & $\mathbf{3 , 8 3}$ \\
$\mathbf{6}$ & Standar Sarana dan Prasarana Pendidikan & $\mathbf{3 , 1 6}$ & $\mathbf{3 , 3 7}$ & $\mathbf{3 , 6 3}$ \\
7 & Standar Pengelolaan Kependidikan & $\mathbf{5 , 0 4}$ & $\mathbf{5 , 5 4}$ & $\mathbf{5 , 3 7}$ \\
$\mathbf{8}$ & Standar Pembiayaan & $\mathbf{5 , 2 4}$ & $\mathbf{5 , 5 6}$ & $\mathbf{5 , 9 8}$ \\
\hline
\end{tabular}

Sumber: Rapor Mutu SMK Kartika IV-1 Malang 2018

\section{Implementasi MMT pada SPMP}

Sistem Penjaminan Mutu Pendidikan (SPMP) internal telah dilakukan oleh sekolah, meliputi: Pertama, penetapan standar mutu. Sekolah membuat standar mutu berdasarkan pedoman yang diberikan oleh pemerintah, melalui Dinas Pendidikan Provinsi Jawa Timur yang menaungi sekolah menengah kejuruan. Format dan ketentuan standar yang ada telah diberikan oleh dinas. Standarisasi yang diberikan merupakan suatu hal yang tepat karena dengan adanya standarisasi maka sekolah dapat dengan jelas mengetahui posisinya dibandingkan dengan kondisi minimal yang diminta untuk memberikan pelayanan kepada peserta didik. Pada beberapa bagian ditemukan bahwa standar penjaminan mutu yang diberikan pemerintah belum sesuai dengan kondisi lapangan, misalnya saja pada sekolah kejuruan dengan jurusan tata busana, tata boga, dan tata rias seperti SMKS Kartika IV-1 Malang, kelengkapan unit dapur atau unit salon jauh lebih penting untuk ditinjau dibandingkan kelengkapan laboratorium fisika atau kimia.

Kedua, pemetaan standar mutu. Pada tahap ini, sekolah memetakan kondisi dirinya atas standar yang ada. Standar yang digunakan adalah 8 Standar Pelayanan (SNP) Sekolah, yang meliputi standar: lulusan, isi, proses, sarana dan prasarana, pembiayaan, penilaian, pendidik dan tenaga kependidikan, dan pengelolaan kependidikan. Hasil dari penelitian ini memperlihatkan bahwa nilai SMKS Kartika IV-1 Malang secara keseluruhan dari segi lulusan, isi, proses, penilaian, pendidik/tenaga kependidikan, pengelolaan, sarana prasarana, dan pembiayaan semuanya berada di bawah standar nasional. Walau demikian, SMKS Kartika IV-1 Malang masih memiliki nilai yang lebih tinggi secara keseluruhan dari capaian Jawa Timur. Maksudnya adalah bahwa SMKS Kartika-1 Malang masih lebih baik daripada rata-rata sekolah menengah kejuruan di Jawa Timur, walau masih berada di bawah standar nasional. Jika dibandingkan dengan sekolah kejuruan di Kota Malang, masih unggul di lulusan, isi, proses, sarana dan prasarana, dan pembiayaan, sedangkan di standar penilaian, pendidik dan tenaga kependidikan, dan pengelolaan kependidikan, SMK Kartika IV-1 Malang berada di bawah rata-rata pencapaian sekolah kejuruan Kota Malang. Seiring dengan pemetaan mutu yang dilakukan, sekolah juga melakukan Evaluasi Diri Sekolah (EDS) yang menjadi masukan bagi pemetaan mutu. Pada kenyataannya, kedua kegiatan tersebut; pemetaan mutu dan pembuatan EDS; menjadi kegiatan yang berdiri sendiri dan tidak menjadi masukan atau penguatan satu sama lain. Dapat dikatakan bahwa terdapat inefisiensi sumberdaya atas kegiatan tersebut, dan data yang ada menjadi under-use (data tidak dimanfaatkan dengan optimal).

Ketiga, penyusunan rencana. Merupakan kelanjutan dari kegiatan pemetaan mutu. Setelah didapatkan apa yang menjadi kekuatan dan kekurangan dari sekolah atas standar yang ada, maka sekolah dapat menyusun rencana peningkatan mutu ke depan. Dari hasil penelitian data dan wawancara, rencana yang dibuat belum sepenuhnya berpijak pada pemetaan mutu yang ada, disebabkan karena keterbatasan kemampuan sumber daya manusia dalam melakukan analisis untuk menghasilkan rencana strategis, rencana operasional, dan rencana jangka pendek. Selain itu keterbatasan dana juga menjadi alasan utama, karena tanpa ketersediaan dana, maka rencana yang ada diperkirakan tidak dapat direalisasikan. Hal ini menyebabkan rencana dibuat lebih sebagai langkah normatif, dibandingkan dengan langkah strategis. 
Keempat, pelaksanaan rencana pemenuhan mutu. Pelaksanaan atas rencana dilakukan oleh sekolah, tetapi karena rencana yang telah dibuat tidak didetailkan kembali dalam rencana detail jangka pendek, maka pencapaian atas rencana yang dibuat kurang dapat dikendalikan. Pada implementasinya, pelaksanaan disesuaikan dengan kebutuhan yang ada di lapangan dan kurang terkoneksi pada rencana strategis.

Kelima, evaluasi atas rencana. Berdasarkan hasil wawancara, evaluasi merupakan titik terlemah siklus sistem penjaminan mutu internal, bersamaan dengan pelaksanaan. Evaluasi dilakukan melalui rapat rutin bulanan, tetapi tidak terkoneksi secara langsung pada rencana penjaminan mutu.

Berdasarkan pendapat Sallis (2002), keberhasilan implementasi MMT dalam suatu organisasi dapat dilihat dari diterapkannya beberapa hal yang menjadi ciri dari MMT itu sendiri. Hasil implementasi MMT pada SPMP yang diteliti dapat dilihat pada Tabel 3. Ciri yang pertama adalah continous improvement atau perbaikan terus-menerus yang dilakukan organisasi, dalam setiap tahapan kegiatan dan setiap waktu. Sekolah telah melakukan upaya perbaikan melalui penerapan siklus manajemen mutu internal, mulai dari penetapan standar sampai kepada evaluasi. Hanya saja, dalam penerapan perbaikannya belum bersifat terstruktur dan menyeluruh, masih bersifat insidentil dan sporadis.

Tabel 3. Hasil Implementasi MMT pada SPMP

\begin{tabular}{|c|c|c|}
\hline No & Indikator & Kesimpulan \\
\hline 1 & Continus Improvement & $\begin{array}{l}\text { Sudah dicoba diterapkan, belum bersifat terstruktur dan } \\
\text { menyeluruh }\end{array}$ \\
\hline 2 & Kaizen & $\begin{array}{l}\text { Sudah dicoba diterapkan, rencana kurang terintegrasi, perbaikan } \\
\text { yang dilakukan menjadi kurang terukur }\end{array}$ \\
\hline 3 & Perubahan Budaya & $\begin{array}{l}\text { Belum (lingkungan yang kondusif, SOP yang jelas, dan } \\
\text { penghargaan belum ada) }\end{array}$ \\
\hline 4 & Organisasi Berkebalikan & Sudah sesuai \\
\hline 5 & Kedekatan dengan Pelanggan & $\begin{array}{l}\text { Sudah dilakukan tetapi kebutuhan pelanggan belum terpetakan } \\
\text { dengan jelas }\end{array}$ \\
\hline 6 & Pelanggan Internal & Next in Line Analysis belum berjalan \\
\hline 7 & Pemasaran Internal & Sangat terbatas \\
\hline 8 & Profesionalisme & Sudah diupayakan melalui sertifikasi \\
\hline 9 & Kualitas Belajar & Belum menyentuh kebutuhan dasar peserta didik \\
\hline
\end{tabular}

Ciri kedua adalah kaizen atau perbaikan yang dilakukan tahap demi tahap, secara inkremental, tetapi menerus. Hal ini dilakukan oleh sekolah, dengan cara membuat rencana peningkatan mutu sekolah sesuai sistem manajemen mutu sekolah. Siklus kegiatan manajemen mutu juga dicoba untuk dijalankan walaupun belum sepenuhnya. Pembuatan standar mutu, pemetaan mutu, perencanaan peningkatan, pelaksanaan, dan evaluasi dilakukan. Hanya saja, keterbatasan sumber daya manusia dan dana menyebabkan rencana kurang terintegrasi, dan perbaikan yang dilakukan menjadi kurang terukur. Demikian juga tahapan evaluasi seringkali tidak dilaksanakan.

Berikutnya adalah perubahan budaya. Hal yang paling berat dari penerapan MMT adalah kenyataan bahwa MMT sendiri bukanlah suatu alat yang dapat digunakan dan dipakai, tetapi merupakan bagian dari budaya organisasi, yang harus dilakukan oleh setiap bagian dan setiap orang dalam organisasi. SohelUz-Zaman dan Anjalin (2016) menyatakan bahwa untuk membuat pelaksanaan MMT berhasil adalah menciptakan 'budaya mutu'. Budaya mutu adalah sistem yang berbagi nilai, keyakinan, dan norma yang fokus terhadap pemuasan pelanggan dan perbaikan berkelanjutan terhadap kualitas produk dan layanan. Berdasar Sallis (2002) diperlukan dua hal untuk membangun lingkungan yang kondusif bagi budaya mutu. Hal yang mendasar adalah adanya peraturan dan prosedur yang jelas yang memudahkan karyawan untuk menyesuaikan diri dan adanya penghargaan atas pencapaian karyawan atas mutu organisasi. Sekolah telah membangun budaya mutu, salah satunya dengan membentuk tim penjaminan mutu sekolah pada tahun 2018. Selain itu, terdapat peraturan-peraturan yang dikeluarkan sekolah melalui SK kepala sekolah. Peraturan yang ada belum ditindaklanjuti dengan pembuatan Standard Operating Procedure 
(SOP) untuk setiap kegiatan yang ada. Selain itu, sekolah belum sepenuhnya menerapkan penghargaan (reward) atas pencapaian suatu standar mutu organisasi. Sebuah pencapaian kurang dirasakan secara langsung manfaatnya oleh karyawan karena tidak adanya penghargaan atas pencapaian tersebut. Hal ini juga menyebabkan budaya untuk mengejar mutu terbaik kurang terbangun di sekolah.

Ciri keempat adalah organisasi yang berkebalikan. Melalui wawancara yang dilakukan, dapat disimpulkan bahwa pada dasarnya sekolah telah memahami dan menerapkan bahwa pelanggan utama sekolah adalah peserta didik, dengan demikian unsur guru dan tenaga kependidikan termasuk kepala sekolah berusaha melayani kebutuhan dari peserta didik seoptimal mungkin.

Keberhasilan dari MMT juga dapat dilihat dari implementasi kedekatan dengan pelanggan. Guru secara khusus telah berupaya memberikan pelayanan terbaik kepada peserta didik, salah satunya melalui penambahan jam tambahan pelajaran bagi peserta didik yang akan menghadapi ujian akhir sebelum jam pelajaran dimulai atau pada hari libur akhir pekan. Permasalahan yang sering muncul yaitu tingkat partisipasi peserta didik sangat rendah sehingga kegiatan tidak dapat berjalan optimal. Permasalahan yang dihadapi peserta didik belum sepenuhnya terjawab sehingga upaya yang dilakukan oleh pihak sekolah tidak mendapat respon yang diharapkan. Pendalaman atas permasalahan yang dihadapi oleh peserta didik perlu dilakukan sehingga kebutuhan peserta didik dan upaya yang dilakukan pihak sekolah dapat sejalan.

Implementasi berikutnya adalah perhatian kepada pelanggan internal dan penerapan pemasaran internal. Di dalam sekolah, setiap bagian adalah penting dan akan mempengaruhi bagian yang lain. Dalam next in-line analysis, setiap bagian perlu memperhatikan siapa yang akan mendapatkan dampak langsung dari pekerjaan yang ia lakukan. Misalnya, bagian perencanaan anggaran menyadari bahwa anggaran yang ia rencanakan akan berdampak pada bagian pengajaran untuk satu tahun ke depan. Atau guru akan berpikir ulang untuk datang terlambat jika mengingat keterlambatannya akan mempengaruhi peserta didiknya mendapatkan pengajaran yang baik dan merugikan peserta didiknya. Hal ini telah dilakukan oleh kepala sekolah kepada guru-guru, dan juga kepada tenaga kependidikan lainnya. Kurang efektifnya upaya ini dikarenakan belum adanya SOP yang lengkap dan konsekuensi atas terpenuhi/ tidak terpenuhinya SOP tersebut, sehingga seringkali suatu peraturan dilakukan kurang konsisten, dan masih harus diingatkan secara terus-menerus. Ciri pemasaran internal sudah dilakukan oleh kepala sekolah melalui rapat internal dengan tenaga kependidikan dan juga pihak orangtua peserta didik, dengan menyampaikan target mutu yang diharapkan. Kepala sekolah juga selalu mengingatkan bahwa pencapaian Standar Nasional Pelayanan perlu terus diperhatikan sebagai indikator pencapaian mutu. Hanya saja sifatnya masih sering terputus dan tidak konsisten.

Adapun indikator berikutnya adalah profesionalisme. Profesionalisme adalah melakukan tugas jabatan dengan baik sehingga tujuan dari jabatan tersebut dapat tercapai. Dalam hal ini tetap perlu diingat bahwa profesionalisme menjadi bagian dari pelayanan pelanggan sehingga profesionalisme tidak bisa hanya berhenti pada tahap seorang guru telah menjalankan tugasnya, telah memiliki latar belakang pendidikan yang sesuai dan sertifikat profesi yang tepat, tetapi lebih jauh perlu memahami kebutuhan peserta didik. Pada SMKS Kartika IV-1 Malang, kepala sekolah dan guru telah berupaya untuk memenuhi tuntutan profesional melalui pendidikan dan kompetensinya. Hal yang perlu ditingkatkan adalah pemahaman bahwa profesionalisme ditujukan kepada kebutuhan peserta didik, sehingga upaya perbaikan diri terus dilakukan dan tidak hanya bergantung kepada institusi.

Kualitas pembelajaran juga menjadi indikator dari keberhasilan penerapan MMT. Kualitas pembelajaran telah diupayakan oleh sekolah ini dengan menyediakan kurikulum yang sesuai ketentuan, sarana dan prasarana yang mendukung keberhasilan pencapaian kegiatan belajar, guru dan tenaga kependidikan yang mendukung, proses pembelajaran yang mendukung ketercapaian. MMT membutuhkan lebih dari itu karena MMT mengarah kepada kepuasan pelanggan, dalam hal ini peserta didik, dan bukan target kepala sekolah, guru, komite, atau orangtua. Dengan demikian, kualitas pembelajaran yang diharapkan akan lebih bersifat individual dan berbeda untuk setiap orang. Diperlukan upaya yang keras dari setiap pihak baik guru maupun peserta didik untuk dapat mencapainya. Selain itu keterlibatan orangtua dan pihak lain seperti dunia usaha dan dunia industri (DU-DI) juga tidak dapat ditinggalkan. 


\section{Hal yang Mendukung dan Menghambat Ketercapaian MMT}

Berdasarkan wawancara dan telaah dokumen, maka didapatkan hal-hal yang dianggap dapat mendukung atau menghambat MMT di SMKS IV-1 Malang sebagaimana Tabel 4 berikut.

Tabel 4. Pendukung dan Penghambat MMT

\begin{tabular}{|c|c|c|}
\hline No & Indikator & Kesimpulan \\
\hline 1 & Pendidikan dan Pelatihan (Diklat) & ++ \\
\hline 2 & Manajemen Kualitas & - \\
\hline 3 & Pemberdayaan dan Pelibatan Karyawan & ++ \\
\hline 4 & Pernyataan Visi & - \\
\hline 5 & Pendetailan Rencana & - \\
\hline 6 & Penghargaan Prestasi & - \\
\hline 7 & Fokus Pelanggan & ++ \\
\hline 8 & Komitmen Pemimpin Puncak & ++ \\
\hline 9 & Kepemimpinan & - \\
\hline 10 & Budaya Orientasi Mutu & - \\
\hline 11 & Komunikasi & - \\
\hline 12 & Resistensi Pegawai & (Ada Resistensi) \\
\hline 13 & Sumberdaya (sumberdaya manusia, dana, sarana prasarana) & - \\
\hline
\end{tabular}

Pelaksanaan pendidikan dan pelatihan mutu dinyatakan dari penelitian Mosadeghrad (2012) dan Arshida dan Agil (2013), sebagai hal yang dapat menjadi pendukung jika dilaksanakan dan penghambat jika tidak dilakukan. Pelatihan yang menyangkut pemahaman terhadap mutu sekolah dilaksanakan oleh Dinas Pendidikan dan diikuti oleh guru dan tenaga kependidikan, tetapi lebih kepada teknis bagaimana membuat standar mutu, bagaimana membuat pemetaan mutu, sesuai dengan format aplikasi yang diberikan pemerintah. Ini pun masih dilakukan sangat terbatas kepada beberapa orang tertentu saja. Pemahaman secara utuh tentang manajemen mutu dan penerapannya belum dilakukan. Setiap pihak yang terlibat, khususnya yang termasuk dalam tim penjaminan mutu harus mendapatkan pelatihan mutu tersebut. Sementara dari data wawancara, hanya sebagian kecil orang yang terlibat, yaitu Ketua Penjaminan Mutu Sekolah dan seorang operator. Pelatihan mutu secara informal dilakukan oleh pengawas sekolah yang mengajarkan ketua penjamin mutu sekolah untuk dapat mengikuti sistem penjaminan mutu sekolah sesuai siklus yang diberikan.

Manajemen Kualitas telah diupayakan oleh pihak sekolah dengan cara mengikuti tahapan dalam sistem penjaminan mutu, walaupun masih sebatas sebagian saja belum keseluruhan sistem, seperti evaluasi terhadap rencana belum banyak mendapat perhatian. Di dalam penerapan keseharian terhadap semua orang dan pihak yang terlibat, belum sepenuhnya terlaksana, masih terfokus pada kepala sekolah dan sebagian guru. Sebagian guru dan tenaga kependidikan, orang tua, komite sekolah, dan juga peserta didik belum sepenuhnya terlibat dalam menjalankan perannya masing-masing sesuai dengan standar mutu.

Pernyataan visi mutu telah dinyatakan di dalam standar mutu berupa acuan mutu sekolah. Acuan mutu sekolah ini mengacu kepada standar sesuai ketentuan yang berlaku. Acuan mutu utama adalah Standar Nasional Pendidikan yang menjadi kriteria minimal yang harus dipenuhi oleh sekolah. Tetapi sebagai sebuah kesatuan mutu (yang merangkum ke-8 SNP tersebut), belum terdapat di dalam dokumen sekolah. Pernyataan ini belum terlalu banyak diterapkan dan disosialisasikan kepada pihak lainnya, sehingga walaupun kegiatan yang dilaksanakan didasarkan pada visi mutu yang ada, belum semua pihak menyadari bahwa apa yang dilakukan menjadi bagian dari perwujudan visi mutu sekolah. Selanjutnya, visi mutu sekolah perlu diperjelas dengan rencana yang sejalan dengan visi mutu. Rencana yang dibuat oleh sekolah sebagian telah didasarkan atas pemetaan mutu yang dibuat dan sebagian belum sesuai. Keterbatasan sumber daya manusia bidang perencanaan dan penjaminan mutu serta keterbatasan dana 
menjadi penyebab utama. Demikian juga dengan rencana perubahan atau alternatif rencana sementara ini belum dibuat, tetapi persoalan ini diatasi dengan melakukan rapat rutin bulanan ataupun 2 mingguan di mana persoalan yang dihadapi akan dipecahkan bersama-sama.

Penghargaan terhadap prestasi karyawan dapat mempengaruhi penerapan mutu di dalam organisasi. Penghargaan yang diberikan merupakan pembeda antara pencapaian mutu dan tidak, sehingga guru ataupun tenaga kependidikan yang telah berusaha untuk meningkatkan mutu, pada waktu tertentu perlu mendapatkan penghargaan atas upayanya. Hal ini sesuai dengan hasil wawancara, ketua penjamin mutu SMKS Kartika IV-1 Malang menyampaikan bahwa guru dan tenaga kependidikan telah berusaha untuk terus menjaga dan meningkatkan mutu sekolah. Hanya saja sekolah belum dapat memberikan penghargaan, terutama dalam bentuk penambahan kesejahteraan, walaupun berjumlah kecil dari segi nominal, yang dapat menjadi penyemangat bagi karyawan yang melakukan peningkatan mutu. Sedangkan di satu sisi konsekuensi kehilangan kesempatan mendapatkan bonus akan terjadi jika mutu tidak tercapai. Suleman dan Gul (2015) dalam penelitiannya terhadap sekolah menengah atas di Pakistan menyatakan bahwa status dan moral guru yang rendah karena kurangnya penghargaan termasuk upah yang tidak layak, merupakan faktor utama yang secara negatif mempengaruhi keberhasilan implementasi MMT.

Keberhasilan ataupun kekurangan juga bergantung pada fokus mutu kepada pelanggan. Fokus pelayanan pelanggan di sekolah harus berfokus pada peserta didik., Peserta didik di SMKS Kartika IV-1 Malang telah dilibatkan di dalam pengisian pemetaan mutu sekolah. Memahami kebutuhan peserta didik juga dilakukan oleh guru dengan cara menganalisis melalui hasil belajar peserta didik. Jika dianggap masih rendah, maka upaya perbaikan dilakukan melalui pemberian jam tambahan bagi mereka, pemberian ujian-ujian try out bagi kelas XII. Tetapi masih terdapat peserta didik yang justru tidak memanfaatkan fasilitas ini dan pada akhirnya tidak dapat mencapai prestasi yang baik. Perlu diperhatikan bahwa kemungkinan kebutuhan peserta didik memang tidak tertuju pada pencapaian nilai dulu, tetapi lebih kepada bangkitnya motivasi belajar dan merasakan manfaat dari belajar. Dengan terlebih dahulu memahami kebutuhan peserta didik dan bukan hanya melihat target pencapaian normatif, maka fokus kepada pelanggan dapat lebih tercapai. Dalam hal ini peserta didik perlu diberikan wawasan dan motivasi untuk mengenali kekurangan dan kelebihannya, keyakinan bahwa cita-cita dapat diraih dengan semangat dan kepercayaan diri, lebih penting untuk dibangun terlebih dahulu dibandingkan pencapaian akademik.

Indikator berikutnya adalah adanya komitmen pemimpin puncak. Dari hasil wawancara terlihat bahwa keterlibatan pemimpin puncak di sekolah, yaitu kepala sekolah sudah nampak. Hal ini terlihat dari aktivitas kepala sekolah dalam setiap rapat untuk mengingatkan para guru dan tenaga kependidikan lainnya untuk melakukan perbaikan demi keberhasilan peserta didik. Kepala sekolah juga telah membentuk tim penjamin mutu sekolah dan mendorong untuk mendapatkan pelatihan dari pengawas sekolah. Peneliti mencermati bahwa komitmen kepala sekolah sudah nampak, tetapi karena SMK ini merupakan SMK swasta yang bernaung di bawah yayasan, maka kepedulian dan komitmen dari ketua yayasan akan sangat mempengaruhi keberhasilan penerapan manajemen mutu terpadu di sekolah. Abdaziz (2015) menyatakan bahwa komitmen pemimpin merupakan faktor kunci yang menjamin kesuksesan implementasi MMT di dalam suatu organisasi.

Dokumen sistem penjaminan mutu internal dan hasil wawancara menunjukkan bahwa kegiatan yang mengarah kepada peningkatan mutu sekolah telah ada tetapi belum menjadi budaya berorientasi mutu karena sistem yang ada belum dilaksanakan secara kontinyu tetapi masih terpisah-pisah dan indikator mutu belum diturunkan di dalam Standard Operating Procedures (SOP) sekolah yang bersifat teknis dan keseharian.

Salah satu kendala di dalam penerapan mutu adalah komunikasi. Standar mutu yang terus dikomunikasikan oleh pimpinan kepada bawahan ataupun kepada seluruh stakeholder sekolah, secara terus menerus dan konsisten, perlu dilakukan tersistem dan terkendali (ada indikator keberhasilannya). Komunikasi yang telah dilakukan sekolah telah diupayakan melalui, pelibatan stakeholder di dalam mengisi pemetaan mutu dan melakukan rapat secara rutin berkaitan dengan mutu dan permasalahan 
sekolah. Komunikasi harus selalu disampaikan juga kepada peserta didik maupun komite sekolah dan orang tua, tentang mutu yang dijadikan standar sekolah, para stakeholder tersebut diajak menjadi bagian dari pencapaian mutu tersebut dengan memperlihatkan keuntungan yang dapat dirasakan peserta didik langsung ataupun tidak langsung. Perlu diingat bahwa beban untuk menjaga dan meningkatkan mutu bukan hanya tugas kepala sekolah dan guru tetapi menjadi tanggung jawab semua pihak, keterlibatan semua pihak dalam manajemen mutu inilah yang memang berat dan perlu kerjasama terus-menerus.

Dari hasil wawancara, didapatkan fakta bahwa terdapat resistensi dari sebagian guru dan juga peserta didik dalam melakukan kegiatan penjaminan mutu. Misalnya saja, peserta didik sudah diberitahu bahwa kedisiplinan adalah bagian dari kegiatan menjamin mutu belajar mengajar, tetapi karena tidak konsistennya penghargaan (reward) and hukuman (punishment) yang ada sehingga aturan seringkali diabaikan. Demikian juga dengan para guru, misalnya sudah disampaikan bahwa guru piket setiap 1 jam harus berkelilling ke kelas-kelas memantau jalannya kegiatan belajar mengajar, hanya bertahan 1-2 minggu, setelah itu diabaikan kembali. Hal ini dilakukan karena merasa sudah cukup dengan kondisi yang ada, kondisi seperti yang ada pun (tanpa aturan) sudah dirasakan cukup nyaman, karena tidak memahami dan tidak merasakan langsung manfaat dari kegiatan menjaga dan meningkatkan mutu tadi.

Hal terakhir yang menjadi indikator keberhasilan atau ketidakberhasilan dari penerapan manajemen mutu terpadu adalah ketersediaan atau tidaknya sumberdaya, termasuk di dalamnya: pembiayaan (dana), sarana dan prasarana, dan sumberdaya manusia (terutama dari segi kualitas). Dari hasil wawancara berulangkali disampaikan bahwa permasalahan dana mengakibatkan tidak dapatnya sekolah memberi penghargaan yang layak kepada pihak (guru) yang telah menjaga dan meningkatkan mutu. Sarana dan prasarana sudah cukup baik walaupun masih terdapat kekurangan. Selain itu, kemampuan sumberdaya manusia di dalam memahami dan ikut terlibat dalam peningkatan mutu sekolah sangat terbatas. Menjaga dan meningkatkan mutu sekolah masih menjadi kepedulian sebagian kecil pihak saja.

\section{SIMPULAN DAN SARAN}

\section{Simpulan}

Pertama, keberhasilan implementasi MMT pada Sistem Penjaminan Mutu Pendidikan di sekolah kejuruan, dalam hal ini SMKS Kartika IV-1 Malang, dapat disimpulkan telah diupayakan untuk dilaksanakan, tetapi karena berbagai kendala sumberdaya manusia dan dana, menjadi belum sepenuhnya terstruktur, terukur, dan optimal. Prinsip pertama, yaitu continous improvement, telah diupayakan sekolah melalui penerapan siklus manajemen mutu internal, mulai dari penetapan standar sampai kepada evaluasi. Dalam penerapannya belum bersifat terstruktur dan menyeluruh. Kedua, kaizen. Siklus kegiatan manajemen mutu juga dicoba untuk dijalankan walaupun belum sepenuhnya. Keterbatasan sumber daya manusia dan dana menyebabkan rencana kurang terintegrasi, dan perbaikan yang dilakukan menjadi kurang terukur. Ketiga, perubahan budaya. Penerapan perubahan budaya dapat dicapai melalui dua hal, yaitu memberikan lingkungan yang kondusif bagi perubahan melalui peraturan dan prosedur kerja yang jelas dan memberikan penghargaan kepada karyawan yang mencapai target mutu. Kedua hal ini telah dilakukan di sekolah, tetapi dengan penerapan yang belum optimal, SOP dan penghargaan atas kinerja karyawan masih terbilang kurang. Keempat, organisasi yang berkebalikan. Di dalam penerapan SPMP, pelanggan utama adalah peserta didik dan kemudian guru, hal ini sudah sesuai dengan prinsip MMT bahwa peserta didik menjadi pihak yang paling utama dilayani. Kelima, kedekatan dengan pelanggan. Jam dan ujian tambahan telah diupayakan sekolah, tetapi motivasi dan semangat peserta didik nampaknya merupakan hal yang lebih harus diutamakan untuk menjawab persoalan. Keenam dan ketujuh adalah pelanggan internal dan pemasaran internal. Di dalam penerapan next-in line analysis di dalam penerapan SPMP belum sepenuhnya terwujud berkaitan dengan belum adanya SOP dan konsekuensi yang jelas atas terpenuhi/tidak terpenuhinya SOP tersebut. Pemasaran internal juga telah diupayakan oleh kepala sekolah melalui rapat-rapat internal, tetapi di dalam pelaksanaannya sering terputus dan tidak konsisten. Kedelapan adalah profesionalisme dan kesembilan adalah kualitas pembelajaran. Di dalam kegiatan SPMP, profesionalisme telah diupayakan melalui pemenuhan kualifikasi ataupun sertifikasi yang sesuai, demikian juga dengan kualitas pembelajaran diupayakan untuk dapat memenuhi kebutuhan peserta didik 
dengan menyediakan kurikulum yang sesuai, penyediaan sarana prasarana, guru-guru yang memiliki kualifikasi dan kompetensi. Tetapi jika ditinjau dari pemenuhan kebutuhan peserta didik yang mendasar, seperti misalnya peserta didik yang kurang motivasi dan semangat belajar, hal ini belum tertangani dengan tepat.

Kedua, jika ditinjau dari hal yang mendukung dan menghambat ketercapaian MMT pada penerapan SPMP di SMKS Kartika IV-1 Malang, dapat dilihat bahwa sebagian indikator telah terpenuhi. Pendidikan dan pelatihan, pemberdayaan dan pelibatan karyawan, fokus kepada pelanggan, komitmen pemimpin puncak, telah diupayakan oleh sekolah. Masih terdapat beberapa kekurangan di beberapa bagian, tetapi secara umum telah ada kesadaran melakukannya untuk menjamin mutu. Pada indikator lainnya, masih terdapat kelemahan, seperti belum jelasnya pernyataan visi mutu dan belum detailnya rencana penerapan sasaran mutu yang dibuat dan bagaimana rencana perubahannya, penghargaan terhadap prestasi karyawan dalam mencapai sasaran mutu juga belum terlihat. Walaupun komitmen pemimpin puncak, dalam hal ini kepala sekolah, telah cukup kuat, tetapi di dalam kepemimpinan belum cukup kuat, sehingga seringkali rencana yang dibuat tidak dapat dilaksanakan dengan baik karena tidak adanya kepemimpinan yang tegas dari kepala sekolah. Demikian juga budaya berorientasi mutu masih menjadi kepedulian sebagian orang saja dan belum menjadi budaya organisasi. Komunikasi yang dibangun dalam menjalankan SPMP masih terbatas dalam bentuk pelibatan dalam pemetaan mutu dan dalam rapat-rapat rutin. Adapun resistensi guru, tenaga kependidikan, bahkan dari peserta didik, juga ada. Di sisi lain keterbatasan sumberdaya berupa dana yang kurang, sarana prasarana yang terbatas, dan sumberdaya manusia yang memiliki kemampuan dan kemauan dalam menjaga dan mempertahankan mutu masih menjadi hambatan keberhasilan SPMP.

\section{Saran}

Penerapan MMT pada SPMP di SMKS Kartika IV-1 Malang, perlu memperhatikan beberapa hal-hal agar penerapannya di kemudian hari berjalan lebih baik. Pertama, visi mutu perlu dinyatakan dalam peraturan yang formal, dan terus didengungkan isi dan tujuannya kepada seluruh stakeholder yang terlibat. Kedua, rencana strategis dalam mencapai sasaran mutu sesuai dengan hasil pemetaan mutu perlu dituangkan secara detail disertai dengan indikator sehingga pencapaiannya dapat lebih terukur. Ketiga, sesuai dengan siklus SPMP internal, rencana strategis ini harus merupakan kelanjutan dari pemetaan mutu yang ada, sehingga menjadi sebuah kesatuan yang utuh dan terstruktur. Keempat, langkah berikut yang tidak dapat dilewatkan adalah evaluasi. Evaluasi merupakan bagian yang tidak terpisahkan dari penjaminan mutu dan tetap perlu melibatkan berbagai stakeholder. Tanpa adanya evaluasi maka kegiatan penjaminan mutu menjadi tidak berkesinambungan. Kelima, SOP dan peraturan yang jelas perlu dibangun karena akan sangat membantu dalam kegiatan penjaminan mutu. Langkah keenam, penghargaan terhadap guru dalam pencapaian mutu perlu dilakukan sebagai penyemangat dan juga indikator individu untuk memenuhi target mutu. Ketujuh, kepemimpinan yang kuat perlu terus dikembangkan di dalam menjalankan sistem penjaminan mutu pendidikan.Terakhir adalah budaya mutu perlu terus dikembangkan di dalam sekolah, melalui komunikasi intensif untuk membangun motivasi tentang tujuan, manfaat, dan bagaimana cara masing-masing individu berperan menjaga dan meningkatkan mutu sekolah. Hal ini juga sekaligus dilakukan untuk mengatasi resistensi dari unsur internal sekolah dalam penerapan penjaminan mutu.

\section{DAFTAR RUJUKAN}

Abdaziz, A. 2015. The Impact of Total Quality Management on Organizational Performance. European Journal of Business and Management. Vol.7 No.36.

Arshida, M.M. \& Agil, S.O. 2013. Critical Success Factors for Total Quality Management Implementation Within The Libyan Iron and Steel Company. ISS \& MLB. Kualalumpur. Malaysia.

Crawford, L.E.D. \& Shutler, P. 1999. Total Quality Management in Education: Problems and Issues for the Classroom Teacher. The International Journal of Education Management 13/2. 
Ismail, S.N. 2014. Total Quality Management (TQM) Practices and School Climates Amongst High, Average, and Low Performance Secondary School. Malaysian Journal and Learning of Instruction. Vol.11.

Mosadeghrad, A.M. 2012. Why TQM programmes fail? A pathology approach. Health Management and Economics Research Centre, Tehran University of Medical Sciences, Teheran, Iran

Pekkar, J.K. 1995. Total Quality Management: Guiding Principles for Applications. ASTM. Philadelphia USA.

Robbins, Stephen P. Coulter, Mary. 1999. Management. Prentice Hall International, Inc.

Sallis, Edward. 2002. Total Quality Management in Education. Third edition. Kogan Page. UK.

Sohel-Uz-Zaman, A.S.Md. \& Anjalin, U. 2016. Implementing Total Quality Management in Education: Compatibility and Challenges. Open Journal of Social Sciences, 2016,4,207-217.

Suleman, Q. \& Gul, R. 2015. Challenges to Successful Total Quality Management Implementation in Public Secondary Schools: A Case Study of Kohat Distric,Pakistan. Journal of Education and Practice. Vol.6. No. 15. 